\title{
Middle range theory for the nursing diagnosis Excess Fluid Volume in pregnant women
}

\author{
Teoria de médio alcance para o diagnóstico de enfermagem Volume de Líquidos Excessivo em gestantes \\ Teoría de medio alcance para el diagnóstico de enfermería Volumen de Liquidos Excesivo en gestantes
}

\begin{tabular}{r}
\hline Nathaly Bianka Moraes Fróes' \\
ORCID: 0000-0002-1793-9829 \\
Marcos Venícios de Oliveira Lopes' \\
ORCID: 0000-0001-5867-8023 \\
Cleide Maria Pontes' \\
ORCID: 0000-0003-4707-6873 \\
Gabriele Lima Ferreira' \\
ORCID: 0000-0003-3279-1399 \\
Priscila de Souza Aquino' \\
ORCID: 0000-0003-4976-9817
\end{tabular}

'Universidade Federal do Ceará. Fortaleza, Ceará, Brazil. "Universidade Federal de Pernambuco. Recife, Pernambuco, Brazil.

How to cite this article:

Fróes NBM, Lopes MVO, Pontes CMP, Ferreira GL, Aquino PS. Middle range theory for the nursing diagnosis Excess Fluid Volume in pregnant women. Rev Bras Enferm. 2020;73(Suppl 4):e20190334. doi: http://dx.doi.org/10.1590/0034-7167-2019-0334

\section{Corresponding author:}

Nathaly Bianka Moraes Fróes

E-mail: nathaly.bmf@hotmail.com

EDITOR IN CHIEF: Dulce Barbosa ASSOCIATE EDITOR: Ana Fátima Fernandes

Submission: 07-20-2019

Approval: 04-17-2020

\section{ABSTRACT}

Objective: To stablish a middle range theory for the understanding of the causal mechanisms and clinical consequentes of the nursing diagnosis Excess Fluid Volume (00026) among pregnant women. Method: The Middle Range Theory was constructed in five stages: defining of construction approach, establishing main concepts, elaborating propositions, developing a pictorial diagram, and establishing the causal relationships and evidence for practice of the Middle Range Theory. Results: We identified 14 clinical indicators and 6 causal factors of Excess Fluid Volume. A pictorial diagram was developed and relationships between Excess Fluid Volume elements were established with 6 propositions for them. Conclusion: The Middle Range Theory included both physiological and pathological conditions to explain Excess Fluid Volume. This Middle Range Theory might help in the better understanding of interactions between causal factors and clinical indicators of Excess Fluid Volume.

Descriptors: Nursing Diagnosis; Pregnancy; Nursing Theory; Review; Women's Health.

\section{RESUMO}

Objetivo: Estabelecer uma teoria de médio alcance para a compreensão dos mecanismos causais e consequências clínicas do diagnóstico de enfermagem Volume de Líquidos Excessivo (00026) em gestantes. Métodos: A Teoria de Médio Alcance foi construída em cinco etapas: Definição da abordagem de construção; Definição dos conceitos principais; Desenvolvimento de um esquema pictorial; Construção das proposições e Estabelecimento das relações de causalidade e de evidências para a prática. Resultados: Foram identificados 14 indicadores clínicos e 6 fatores causais de Volume de líquidos excessivo. Foi construído um diagrama pictorial e estabelecidas relações entre os elementos de Volume de líquidos excessivo, com seis proposições para eles. Conclusão: A Teoria de Médio Alcance incluiu tanto condições fisiológicas como patológicas para explicar o Volume de Líquidos Excessivo. A Teoria de Médio Alcance pode ajudar na melhor compreensão das interações entre os fatores causais e indicadores clínicos de Volume de líquidos excessivo.

Descritores: Diagnóstico de Enfermagem; Gravidez; Teoria de Enfermagem; Revisão; Saúde da Mulher.

\section{RESUMEN}

Objetivo: Establecer una teoría de medio alcance para la comprensión de los mecanismos causales y consecuencias clínicas del diagnóstico de enfermería Volumen de Líquidos Excesivo (00026) en gestantes. Métodos: La teoría de medio alcance ha sido construida en cinco etapas: Definición del abordaje de construcción; Definición de los conceptos principales; Desarrollo de un esquema pictorial; Construcción de las proposiciones; y Establecimiento de las relaciones de causalidad y de evidencias para la práctica. Resultados: Han sido identificados 14 indicadores clínicos y 6 factores causales de Volumen de Líquidos Excesivo. Ha sido construido un diagrama pictorial y establecidas relaciones entre los elementos de Volumen de Líquidos Excesivo, con seis proposiciones para ellos. Conclusión: La teoría de medio alcance incluyó condiciones fisiológicas y patológicas para explicar el Volumen de Líquidos Excesivo; ella puede ayudar en la mejor comprensión de las interacciones entre los factores casuales e indicadores clínicos de Volumen de Líquidos Excesivo.

Descriptores: Diagnóstico de Enfermería; Embarazo; Teoría de Enfermería; Revisión; Salud de la Mujer. 


\section{INTRODUCTION}

The nursing diagnosis (ND) Excess fluid volume (EFV) (00026) is defined as the excessive fluid intake and/or fluid retention. It was incorporated to NANDA-I taxonomy in 1982 and revised in the years of 1996, 2013 and 2017. Currently, it belongs to the domain Nutrition and the class Hydration in the version 2018-2020 of NANDA-I and, in the latest review, this ND has level of evidence of 2.1. ${ }^{(1)}$.

EFV might appear both in physiological conditions - pregnancy-as pathological conditions - cirrhosis, congestive heart failure, chronic renal failure. About $60 \%$ of an adult human body is made by fluids, specially, an aqueous solution of ions and other substances. About one third of this fluid is extracellular ${ }^{(2)}$. Special mechanisms for ions transport, through cell membranes, keep the difference of ionic concentration between the extracellular and intracellular fluids ${ }^{(2)}$. Extracellular fluid regulation is similar to blood pressure regulation and it is made through adjustments in sodium metabolism. Effective intravascular volume is equivalent to the arterial system intravascular volume, it is responsible for tissue infusion and aortic arch, carotid sinus and kidney baroreceptors stimulation ${ }^{(2)}$.

Imbalance in these mechanisms may lead to the appearance of EFV. Alterations in effective intravascular volume, noticed by the baroreceptors afferent sensor system, determine the activation of the effector systems that aim to restore normovolemia through adjustments in the peripheral vascular resistance, cardiac output and, mainly, renal excretion of sodium ${ }^{(3)}$.

One of the physiological causes to the increase in fluid volume is pregnancy. One of the most frequent complaints of pregnant women consist of lower limbs edema and, in some of them, the edema occurs in the face and upper limbs. Physiologically, there is plasmatic volume expansion from 40 to $50 \%$, decreasing components concentration such as hematocrit and hemoglobin, that don't increase in the same proportion as plasma does ${ }^{(4)}$. Furthermore, some of the alterations that occur during pregnancy may cause excess fluid, modifying regulatory mechanisms of women's body.

In specific, albumin decreases to about $1 \mathrm{~g} / 100 \mathrm{ml}$, decreasing colloidosmotic pressure and changing osmolarity, allowing bigger extravasation to the extracellular space. Besides, changes in blood volume during pregnancy are due to stimulation of the reninangiotensin-aldosterone system, mediated by estrogen, resulting in water and sodium retention ${ }^{(4)}$. In pathological pregnancy situations, physiological alterations of pregnancy are exacerbated, leading to more serious clinical indicators of EFV. In preeclampsia and eclampsia, for example, there are anasarca, orthopnea, oligury and others ${ }^{(5)}$.

The EFV Associated Condition (AC) Compromised regulatory mechanisms contains a variety of options that are not exposed by the author. Pregnancy, hepatopathy, hormonal disturbs are amongst them ${ }^{(6)}$.Thus, EFV might appear through several clinical conditions. That implies a considerable number of regulatory mechanisms that might be compromised in order to lead to the nursing diagnosis.

Therefore, a further deepening around the causal factor, clinical indicator, as well as the existent correlations between these elements is necessary for the adequate comprehension of the dynamic involving water balance among pregnant women. At this point, the development of a middle range theory (MRT) might clarify the dynamic of excess fluid volume and guide its use in the professional assistance.
Middle range theories have a more restricted scope and are more interested in less abstract and more specific phenomena, they are composed by few concepts and propositions ${ }^{(7)}$. That allows the development of empirical proofs, which can adjust to the comprehension and needs of nursing ${ }^{(8-9)}$. Furthermore, these theories might assist in nursing practice by facilitating the understanding of patient behaviors, suggesting interventions and providing explanations for interventions degrees of efficacy ${ }^{(10)}$.

MRT might provide phenomena description, explanations of the relations between multiple concepts and phenomena prediction $^{(11)}$. This last approach is directed to stablish precise relationships between concepts aiming to describe how changing within a phenomenon occur ${ }^{(7)}$. That way, from a predictive middle range theory the mechanisms that explain the occurrence of EFV in pregnant women can be stablished and so can the ways in which its causal factors lead to the clinical indicators that appear in that population.

\section{OBJECTIVE}

To stablish a middle range theory for the understanding of the causal mechanisms and clinical consequents of the nursing diagnosis Excess Fluid Volume (00026) among pregnant women.

\section{METHODS}

The construction of the middle range theory for EFV in pregnant women was developed on five stages: Defining the approach to construct the MRT; Definition of the mains concepts of the MRT; Developing a pictorial diagram. Construction of propositions; and Establishment of causal relationships and evidence for practice. The deductive model was chosen to build this MRT, considering its combinations of ideas of a variety of areas of inquiry and scientific bases $^{(10)}$.

\section{Defining the approach to construct the Middle Range Theory}

The first and second stages were developed based on an integrative review of the literature. This review aimed to identify the main and secondary concepts of the MRT that included the conceptual definitions of each clinical indicator and etiological factor. PRISMA (Preferred Reported Items for Systematic Reviews and Meta-Analysis) recommendations were followed in the present study, except for items 4, 5, 12, 14-16, 19-23, which do not apply for integrative reviews ${ }^{(12)}$.

The bibliographic collection used to the development of this study included books and articles related to physiological and pathological changes during pregnancy that may result in fluid retention, without year or language restriction.

The data basis consulted were Scielo, Lilacs, Scopus, CINAHL and PubMed, using the descriptor pregnancy linked to descriptors related to defining characteristics of EFV. Descriptors used to the identification of the defining characteristics included Edema AND Pregnancy, Anasarca AND Pregnancy, Weight gain AND Pregnancy, Azotemy AND Pregnancy, Hematocrit AND Pregnancy, Hemoglobin AND Pregnancy, Dyspnea AND Pregnancy, Electrolytes AND Pregnancy, Venous pressure AND 
Pregnancy, Fluid intake AND Pregnancy, Oligury AND Pregnancy, Orthopnea AND Pregnancy, Paroxysmal dyspnea AND Pregnancy, Pleural effusion AND Pregnancy, Jugular vein AND Pregnancy, Pulmonary congestion AND Pregnancy, Agitation AND Pregnancy, Anxiety AND Pregnancy, Third heart sound AND Pregnancy, Hepatomegaly AND Pregnancy, Breath sounds AND Pregnancy, Blood pressure AND Pregnancy, Pulmonary pressure AND Pregnancy, Breathing pattern AND Pregnancy, Urinary density AND Pregnancy.

Studies that were related to the Clinical indicators of EFV but were not caused specifically by pregnancy or pregnancy related conditions were excluded from this review. During the search, information about clinical indicators of EFV were extracted in each individual search for each clinical indicator. If, during the search for a specific clinical indicator, information about another clinical indicator was found, that information was collected and included in the review.

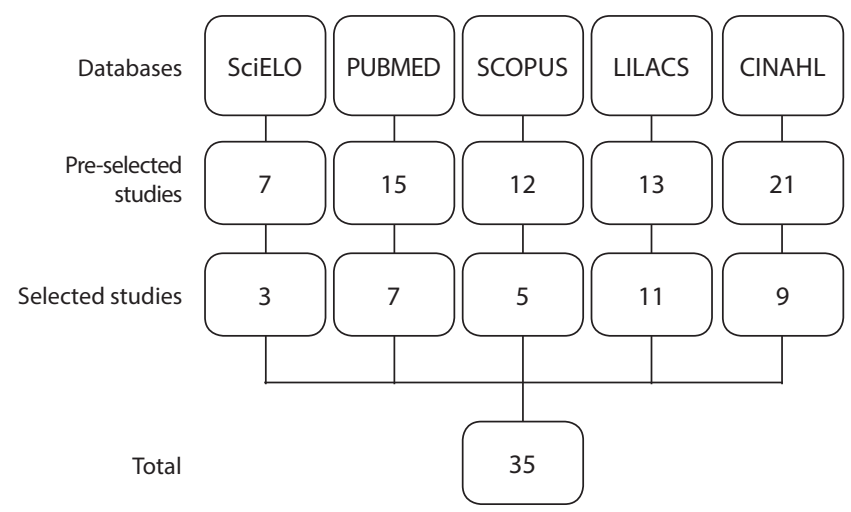

Figure 1 - Fluxogram of search and selection of articles for the integrative review

\section{Definition of the mains concepts of the Middle Range Theory}

For the composition and construction of the MRT three main concepts were utilized: fluid retention, etiological factors and clinical indicators. Initially, we considered the concept of fluid retention proposed by NANDA-I in which fluid retention is defined as the excessive intake and/or fluid retention ${ }^{(1)}$. However, a more specific concept was chosen, that tells us that the fluid retention occurs due to a brake of the controlling mechanisms of volume distribution in the interstitial space ${ }^{(13)}$. That dysregulation might be localized and implicates only factors that affect the fluid flowing among the capillary bed, or, even, might be secondary to alterations in the controlling mechanism of the extracellular compartment volume and the total body water, which, in most of the times, causes generalized fluid retention ${ }^{(14)}$.

Concerning the etiological factor, this study was based on the related factors of EFV describe in NANDA-I taxonomy (Excessive fluid intake, Excessive sodium intake) and the associated condition (Compromised Regulatory Mechanisms) and on the etiological factors identified during the integrative review. However, during the development of the MRT, the related factors described on the taxonomy were reviewed according to the definitions found in the material obtained among the search.

Thus, in this study, the Excessive sodium intake was defined as the increased plasmatic concentration of this ion due to inadequate diet, which may lead to an overload of renal functions, causing fluid retention, difficulting its excretion ${ }^{(5)}$. This related factor is of nursing interest since it is a nurse function to promote pregnant women's health by teaching healthy nutritional habits, therefore reinforcing the importance of a diet with low sodium intake. While the Excessive fluid intake is characterized by the higher fluid intake than the patient can eliminate due to a problem in sodium and water excretion ${ }^{(14)}$. Sodium and water excretion problems during pregnancy are usually linked to hypertensive diseases related to pregnancy, which can be prevented by a healthy lifestyle that is one of the topics in nurse prenatal consultation.

Although the term Compromised regulatory mechanisms represent a wider idea, Boery, Barros \& Lucena (2005) define that Associated Condition as the imbalance between water excretion and intake through pulmonary, urinary and digestive systems due to higher differences in oncotic pressure, anions and cations equivalence and the $\mathrm{pH}$ of body fluids. On the other side, during the present study, this Associated Condition might occur in different ways during pregnancy, as it will be described along the establishment of causal relationship of the Middle Range Theory for this ND. After the reading and analysis of the studies selected for the review, it was formulated the conceptual definitions of clinical indicators of EFV in pregnant women that helped on the establishment of causal relationships for EFV in pregnant women.

The clinical indicators found in the search and their conceptual definitions are described in Chart 1.

Chart 1 - Conceptual definitions for clinical indicators found in this integrative review

\begin{tabular}{|c|c|}
\hline \multicolumn{2}{|c|}{$\begin{array}{l}\text { Clinical Indicators of Excess fluid volume found in the Integrative } \\
\text { Review }\end{array}$} \\
\hline Edema & $\begin{array}{l}\text { Conceptual definition: } \\
\text { Edema is the fluid retention in the interstitial space that } \\
\text { might be local or generalized }{ }^{(15)} \text {. }\end{array}$ \\
\hline $\begin{array}{l}\text { Decreased } \\
\text { hematocrit }\end{array}$ & $\begin{array}{l}\text { Conceptual definition: } \\
\text { Hematocrit indicates the percentage of red blood cells } \\
\text { that is present in a certain amount of blood. During the } \\
\text { gestational period, the increase of plasma on blood } \\
\text { volume surpasses the increase of erythrocytes number, } \\
\text { leading to hemodilution. Average values of hematocrit } \\
\text { for pregnant women are between } 35 \% \text { and } 48 \% \text {. If } \\
\text { the value is below average, it means that there is few } \\
\text { number of erythrocytes for the blood volume }{ }^{(2)} \text {. }\end{array}$ \\
\hline $\begin{array}{l}\text { Decreased } \\
\text { hemoglobin }\end{array}$ & $\begin{array}{l}\text { Conceptual definition: } \\
\text { Hemoglobin is a protein that is inside red blood cells } \\
\text { and transports oxygen from the lungs to the body cells. } \\
\text { During gestation, the phenomenon of hemodilution } \\
\text { leads to a decrease of hemoglobin values in the } \\
\text { pregnant women. The usual values of hemoglobin } \\
\text { during pregnancy are above } 11 \mathrm{~g} / \mathrm{dl}^{(2)} \text {. }\end{array}$ \\
\hline Dyspnea & $\begin{array}{l}\text { Conceptual definition: } \\
\text { Subjective feeling of respiratory difficulty or respiratory } \\
\text { discomfort }^{(5)} \text {. }\end{array}$ \\
\hline $\begin{array}{l}\text { Pulmonary } \\
\text { congestion }\end{array}$ & $\begin{array}{l}\text { Conceptual definition: } \\
\text { Pulmonary congestion occurs when fluid infiltrates in } \\
\text { the lungs faster than it is eliminated, this interferes with } \\
\text { gas exchange at alveolar level(16). }\end{array}$ \\
\hline
\end{tabular}

To be continued 
Chart 1 (concluded)

Clinical Indicators of Excess fluid volume found in the Integrative Review

\begin{tabular}{|c|c|c|c|c|}
\hline \multirow{7}{*}{$\begin{array}{l}\text { Excessive } \\
\text { weight gain } \\
\text { in a short } \\
\text { period of } \\
\text { time }\end{array}$} & \multicolumn{4}{|c|}{$\begin{array}{l}\text { Conceptual definition: } \\
\text { During pregnancy, there are acceptable weight gain } \\
\text { ranges in each gestational trimester and pregnant } \\
\text { women nutritional status. Brasil (2012) stablishes the } \\
\text { following values to weight gain in pregnant women: }\end{array}$} \\
\hline & $\begin{array}{l}\text { BMI (Body } \\
\text { Mass Index) }\end{array}$ & $\begin{array}{l}\text { Total } \\
\text { Weight } \\
\text { Gain on } 1^{\text {st }} \\
\text { trimester }\end{array}$ & $\begin{array}{l}\text { Weekly } \\
\text { Weight Gain } \\
\text { on } 2^{\text {nd }} \text { and } 3^{\text {rd }} \\
\text { trimester }\end{array}$ & $\begin{array}{l}\text { Total Weight } \\
\text { Gain on } \\
\text { gestation }\end{array}$ \\
\hline & Low weight & 2.3 & $0.5 \mathrm{~kg}$ & $12.5-18 \mathrm{~kg}$ \\
\hline & Adequate & $1.6 \mathrm{~kg}$ & $0.4 \mathrm{~kg}$ & $11.5-16 \mathrm{~kg}$ \\
\hline & Overweight & $0.9 \mathrm{~kg}$ & $0.3 \mathrm{~kg}$ & $7-11.5 \mathrm{~kg}$ \\
\hline & \begin{tabular}{|l|} 
Obesity \\
\end{tabular} & - & $0.3 \mathrm{~kg}$ & $7 \mathrm{~kg}$ \\
\hline & \multicolumn{4}{|c|}{$\begin{array}{l}\text { Source: Brasil, } 2012 \text {. } \\
\text { For example, a weekly gestational weight gain of } 400 \mathrm{~g} \\
\text { during the second trimester on a pregnant woman } \\
\text { with adequate BMI before pregnancy is something that } \\
\text { needs to be assessed. }\end{array}$} \\
\hline $\begin{array}{l}\text { Alteration } \\
\text { in blood } \\
\text { pressure }\end{array}$ & \multicolumn{4}{|c|}{$\begin{array}{l}\text { Conceptual definition: } \\
\text { Observation of absolute tensional levels equal or } \\
\text { higher than } 140 \mathrm{mmHg} \text { of Systolic Pressure and equal or } \\
\text { higher than } 90 \mathrm{mmHg} \text { of Diastolic Pressure, sustained in } \\
\text { repeated measurements, under ideal conditions, in at } \\
\text { least three occasions }{ }^{(17)} \text {. }\end{array}$} \\
\hline $\begin{array}{l}\text { Alteration } \\
\text { in arterial } \\
\text { pulmonary } \\
\text { pressure }\end{array}$ & \multicolumn{4}{|c|}{$\begin{array}{l}\text { Conceptual definition: } \\
\text { Arterial pulmonary pressure above usual values. Average } \\
\text { value of systolic arterial pulmonary pressure is } 25 \mathrm{mmHg} \\
\text { and average diastolic pulmonary pressure is } 8 \mathrm{mmHg}^{\mathrm{m}} \\
\text { medium arterial pulmonary pressure is } 15 \mathrm{mmHg}^{(2)} \text {. }\end{array}$} \\
\hline $\begin{array}{l}\text { Increase } \\
\text { in central } \\
\text { venous } \\
\text { pressure }\end{array}$ & \multicolumn{4}{|c|}{$\begin{array}{l}\text { Conceptual definition: } \\
\text { Central venous pressure is regulated by the balance } \\
\text { between heart capacity of pumping the blood outside the } \\
\text { right atrium and ventricle to the lungs and the tendency of } \\
\text { the blood to flow from peripheral veins to the right atrium. } \\
\text { Its normal values are } 2-8 \mathrm{mmHg} \text { (using pressure transducer) } \\
\text { or } 3-11 \mathrm{cmH} 2 \mathrm{O} \text { (using saline solution scale) }{ }^{(2)} \text {. }\end{array}$} \\
\hline Oligury & \multicolumn{4}{|c|}{$\begin{array}{l}\text { Conceptual definition: } \\
\text { Decreased urinary output, despite regular fluid ingestion }{ }^{(5)} \text {. }\end{array}$} \\
\hline Orthopnea & \multicolumn{4}{|c|}{$\begin{array}{l}\text { Conceptual definition: } \\
\text { Respiratory difficulty that appears when patient is in } \\
\text { supine position }{ }^{(5)} \text {. }\end{array}$} \\
\hline $\begin{array}{l}\text { Paroxysmal } \\
\text { nocturnal } \\
\text { dyspnea }\end{array}$ & \multicolumn{4}{|c|}{$\begin{array}{l}\text { Conceptual definition: } \\
\text { Situation in which the patient has her sleep interrupted } \\
\text { due to the breathing difficulty, needing to sit or stand up } \\
\text { in order to obtain relief of the respiratory discomfort }{ }^{(18-19)} \text {. }\end{array}$} \\
\hline Anasarca & \multicolumn{4}{|c|}{$\begin{array}{l}\text { Conceptual definition: } \\
\text { Generalized edema (face, upper and lower limbs), } \\
\text { resulting from fluid retention in the tissues }{ }^{(17)} \text {. }\end{array}$} \\
\hline
\end{tabular}

Clinical indicators are a group of signs and symptoms that assure the presence of a certain diagnose ${ }^{(6)}$. Only clinical indicators pointed out by the literature as relevant for the fluid retention in pregnant women were utilized in this study. In a similar way to the etiological factors, the clinical indicators included those described in NANDA-I (27 defining characteristics) and the ones found during the review. At the end of the search, 13 of the indicators (Table 1) described by NANDA-I were found, no indicator different from the ones described in NANDA-I was found and the search was useful to confirm their relevance to EFV in pregnant women.

\section{Developing a pictorial diagram, Construction of the Middle Range Theory propositions and Establishment of causal relationships and evidence for practice}

After the categorization, analysis and interpretation of the results from the integrative review, a diagram to represent the causal relationships obtained from the middle range theory was developed. Propositions that were based on the diagram and related to each one of the main concepts of the MRT, based on temporal and physiological relationships between the concepts were created. There was also identification and description of causal relationships between the etiological elements and the excess fluid volume based on the model of sufficient cause, where it's established that the interaction among etiological factor, starting from a set of minimum elements, might produce a human specific response $\mathrm{e}^{(20)}$.

\section{RESULTS}

The articles selected to provide the information required to the development of the Middle Range Theory, its authors, years of publication and study design are described on Chart 2.

\section{Middle Range Theory for Excess fluid volume in pregnant women}

The development of the MRT was based on 35 articles identified during the review, adding 2 Obstetrics reference books and 1 Fundamental practice of nursing book. As long for the methodology, among the analyzed articles 16 were review articles, 4 of them were clinical cases, 4 were transversal studies, 1 was longitudinal study, 3 were exploratory studies, 2 were prospective cohort studies, 1 was a case control study, 2 were retrospective studies and 2 were clinical randomized trials.

Chart 2 - Description of the articles included in the integrative review, authors, title and study design

\begin{tabular}{|l|l|l|}
\hline Author/Year & Title & Study desing \\
\hline Moura et al. (2010)(21) & $\begin{array}{l}\text { Fatores de risco para síndrome hipertensiva específica da gestação entre mulheres } \\
\text { hospitalizadas com pré-eclâmpsia. }\end{array}$ & Cross-sectional study \\
\hline Leite, Nóbrega \& Nóbrega (2009)(22) & Diagnósticos de enfermagem em gestantes atendidas em unidade de saúde da família. & Retrospective study \\
\hline Kojima et al. (2013)(23) & Unusual clinical course of preeclampsia heralded by generalized edema. & Clinical case \\
\hline Ponnapula \& Boberg (2010)(24) & Lower Extremity Changes Experienced During Pregnancy. & Retrospective study \\
\hline Santana et al. (2015)(25) & $\begin{array}{l}\text { Food consumption patterns during pregnancy: a longitudinal study in a region of the } \\
\text { North East of Brazil. }\end{array}$ & Prospective cohort study \\
\hline
\end{tabular}

To be continued 
Chart 2 (concluded)

\begin{tabular}{|c|c|c|}
\hline Author/Year & Title & Study desing \\
\hline Costa, Brum \& Lima (2009) $)^{(26)}$ & $\begin{array}{l}\text { Anemia e marcadores séricos da deficiência de ferro em grávidas atendidas na rede } \\
\text { pública municipal de Manaus. }\end{array}$ & $\begin{array}{l}\text { Descriptive transversal } \\
\text { study }\end{array}$ \\
\hline Gernand et al. (2012) 27$)$ & $\begin{array}{l}\text { Maternal Nutritional Status in Early Pregnancy Is Associated with Body Water and } \\
\text { Plasma Volume Changes in a Pregnancy Cohort in Rural Bangladesh. }\end{array}$ & Cluster randomized trial \\
\hline Kaaja \& Greer (2005) & Manifestations of chronic disease during pregnancy. & Integrative review \\
\hline Abbas, Lester \& Connolly $(2005)^{(29)}$ & Pregnancy and the cardiovascular system. & Integrative review \\
\hline Bauer \& Cleary (2009) ${ }^{(30)}$ & Cardiopulmonary complications of pre-eclampsia. & Integrative review \\
\hline Bobrowski $(2010)^{(31)}$ & Pulmonary physiology in pregnancy. & Integrative review \\
\hline Higton, Whale \& Musk (2009) $)^{(32)}$ & Pulmonary hypertension in pregnancy: two cases and review of the literature. & Clinical case \\
\hline Gei \& Rueda $(2014)^{(33)}$ & Pulmonary Hypertension and Pregnancy: An Overview. & Overview \\
\hline Mamun et al. $(2011)^{(34)}$ & $\begin{array}{l}\text { Associations of maternal pre-pregnancy obesity and excess pregnancy weight gains } \\
\text { with adverse pregnancy outcomes and length of hospital stay. }\end{array}$ & Cohort study \\
\hline Belen, Tipi \& Bayyigit (2015) & $\begin{array}{l}\text { Concurrent early-onset peripartum cardiomyopathy in a preeclampsia patient with } \\
\text { acute pulmonary edema. }\end{array}$ & Clinical case \\
\hline Ko et al. $(2005)^{(36)}$ & Massive ascites complicating pre-eclampsia. & Clinical case \\
\hline Razeq $(2011)^{(16)}$ & Obstetric emergencies: Respiratory distress. & Update review \\
\hline Poole \& Spreen $(2005)^{(37)}$ & Acute pulmonary edema in pregnancy. & Integrative review \\
\hline $\begin{array}{l}\text { Guimarães, Barros \& Gutierrez } \\
(2000)^{(6)}\end{array}$ & $\begin{array}{l}\text { Identificação das características definidoras do diagnóstico de enfermagem excesso } \\
\text { de volume de líquidos. }\end{array}$ & Exploratory study \\
\hline Coelho $(2004)^{(13)}$ & Mecanismos de formação de edemas. & Integrative review \\
\hline Boery, Barros \& Lucena (2005) $)^{(14)}$ & $\begin{array}{l}\text { Características definidoras do diagnóstico de enfermagem: volume de líquidos } \\
\text { excessivo. }\end{array}$ & Exploratory study \\
\hline Gil et al, (2010) $)^{(38)}$ & $\begin{array}{l}\text { Prevalencia de los transtornos hipertensivos del embarazo em mujeres embarazadas } \\
\text { controladas en Assbasalud E.S.E, Manizales (Colombia), } 2006 \text { a } 2008 .\end{array}$ & Cross sectional study \\
\hline Albino et al. $(2011)^{(39)}$ & $\begin{array}{l}\text { Modificações da força de propulsão da marcha durante a gravidez: efeito das } \\
\text { alterações nas dimensões dos pés. }\end{array}$ & Case control \\
\hline Henry et al. $(2006)^{(40)}$ & Blood Vessel Changes during Pregnancy A Review & Integrative review \\
\hline Katz et al. $(2008)^{(41)}$ & $\begin{array}{l}\text { Perfil clínico, laboratorial e complicações de pacientes com síndrome HELLP } \\
\text { admitidas em uma unidade de terapia intensiva obstétrica. }\end{array}$ & $\begin{array}{l}\text { Secondary analysis of } \\
\text { randomized clinical trial }\end{array}$ \\
\hline Mochhoury et al. $(2013)^{(42)}$ & $\begin{array}{l}\text { Body Mass Index, Gestational Weight Gain, and Obstetric Complications in Moroccan } \\
\text { Population. }\end{array}$ & $\begin{array}{l}\text { Descriptive transversal } \\
\text { study }\end{array}$ \\
\hline Reiners et al. (2009) $)^{(43)}$ & Diagnósticos de enfermagem em gestantes hipertensas. & $\begin{array}{l}\text { Descriptive exploratory } \\
\text { study }\end{array}$ \\
\hline $\operatorname{Facco}(2011)^{(44)}$ & Sleep-Disordered Breathing and Pregnancy. & Integrative review \\
\hline Alexander \& Wilson $(2013)^{(45)}$ & Hypertensive emergencies of pregnancy. & Integrative review \\
\hline Mighty $(2010)^{(46)}$ & Acute respiratory failure in pregnancy. & Integrative review \\
\hline Gyselaers et al. $(2009)^{(47)}$ & $\begin{array}{l}\text { Doppler assessment of maternal central venous hemodynamics during } \\
\text { uncomplicated pregnancy: a comprehensive review. }\end{array}$ & Integrative review \\
\hline Turner $(2010)^{(48)}$ & $\begin{array}{l}\text { Diagnosis and management of pre-eclampsia: an update. Int J Womens Health, Los } \\
\text { Angeles, California, USA, }\end{array}$ & Update review \\
\hline Assunção et al. (2007)(49) & $\begin{array}{l}\text { Ganho ponderal e desfechos gestacionais em mulheres atendidas pelo Programa de } \\
\text { Saúde da Família em Campina Grande, PB (Brasil) }\end{array}$ & $\begin{array}{l}\text { Prospective longitudinal } \\
\text { study }\end{array}$ \\
\hline Chummun (2009) $)^{(50)}$ & Hypertension - a contemporary approach to nursing care. & Integrative review \\
\hline
\end{tabular}

\section{Etiological factors}

There are many alterations that may lead to fluid retention. Among the acknowledge causes to this phenomenon, in this review, there are chronic diseases, extremes of reproductive age, first pregnancy, vascular alterations related to pregnancy diseases, hormonal changes, excessive sodium intake and mechanical factor. Table 1 shows the frequency of etiological factors and clinical indicators of Excess Fluid Volume in pregnant women found in the results of this review.
Among the analyzed studies, the most frequent factor was the presence of chronic diseases, in which the most frequent disease was the chronic hypertension, followed by obesity and diabetes. The extremes of reproductive age, below or equal 18 years old and above or equal 35 years old and being on the first pregnancy were also pointed out as marked characteristics for the occurrence of Pregnancy Specific Hypertensive Diseases (PSHD) $)^{(19,21)}$. Vascular alterations due to pregnancy specific pathologies had a high frequency due to higher number of studies concerned with PSHD. 
Table 1 - Frequency of etiological factors and clinical indicators of Excess Fluid Volume in pregnant women found in this integrative review

\begin{tabular}{lcc}
\hline Etiological factor & n & $\%$ \\
\hline Chronic diseases & 10 & 30 \\
Vascular alterations related to pregnancy diseases & 8 & 25 \\
Excessive sodium intake & 7 & 21 \\
Hormonal changes & 5 & 17 \\
Mechanical factor & 4 & 12 \\
First pregnancy & 3 & 9 \\
Extremes of reproductive age & 3 & 9 \\
Clinical indicator & $\mathrm{n}$ & $\%$ \\
Edema & 10 & 30 \\
Decrease in hematocrit & 4 & 12 \\
Decrease in hemoglobin & 4 & 12 \\
Dyspnea & 4 & 12 \\
Pulmonary congestion & 4 & 12 \\
Weight gain over short period of time & 4 & 12 \\
Alteration in blood pressure & 3 & 9 \\
Alteration in pulmonary artery pressure & 2 & 6 \\
Increase in central venous pressure (CVP) & 2 & 6 \\
Oligury & 2 & 6 \\
Orthopnea & 2 & 6 \\
Paroxysmal nocturnal dyspnea & 2 & 6 \\
Anasarca & 1 & 6 \\
\hline
\end{tabular}

\section{Clinical indicators}

From the 27 clinical indicators of ND Excessive fluid volume, 14 were identified in the analyzed studies. The remaining characteristics, although identified during the search for articles, were not related with fluid retention, being described as signs or symptoms of other clinical conditions.

\section{Developing a pictorial diagram}

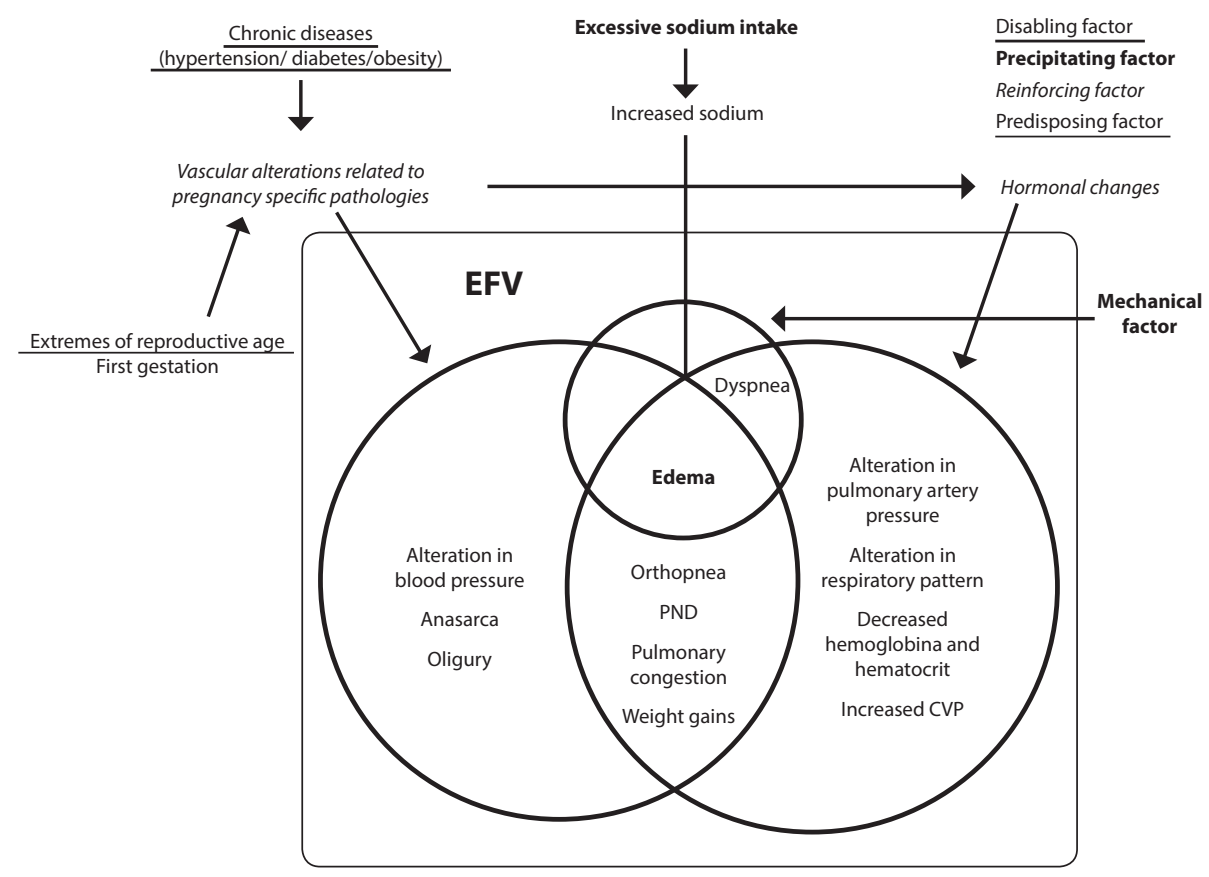

Note: EFV - Excessive fluid volume; PND - Paroxysmal nocturnal dyspnea; CVP - Central Venous Pressure.

Figure 2 - Pictorial diagram representing causal relationships of the middle range theory for Excess fluid volume in pregnant women
Edema was the most frequent clinical indicator among the analyzed productions. It was also the most associated clinical indicator with other EFV indicators, such as alteration in blood pressure, alterations in pulmonary artery pressure, alterations in respiratory pattern, orthopnea, paroxysmal nocturnal dyspnea, pulmonary congestion, weight gain over short period of time and anasarca. Secondarily, clinical indicators decreased hematocrit and decreased hemoglobin were relatively frequent, considering that it is a pregnancy physiological phenomenon. Dyspnea, pulmonary congestion and weight gain over short period of time were also frequent, considering that many of the studies were related to pregnancy specific pathologies that usually cause those symptoms.

\section{Propositions for the Middle Range Theory}

Propositions are principles that are accepted as real without having evidence for $\mathrm{it}^{(7)}$. For the Middle Range Theory developed in this study were elaborated the following propositions:

\section{Propositions}

1. Mechanical factor and excessive sodium intake are precipitating of fluid retention in pregnant women.

2. Extremes of reproductive age and primiparity act as predisposing factors for vascular alterations.

3. Women's exposure to incapacitating factors, as chronic diseases, before pregnancy generates higher possibility for appearance of vascular alteration related complications during pregnancy.

4. Vascular alterations act as reinforcing factors of the consequences of hormonal changes, exacerbating their clinical consequents.

5. Hormonal changes act along with excessive sodium intake, increasing fluid retention.

6. Alteration in pulmonary artery pressure, decreased hematocrit and hemoglobin levels, increased CVP and alterations in respiratory pattern occur due to consequences of hormonal changes.

\section{DISCUSSION}

\section{Establishing causal relationship and evidence for practice}

Leite et al. (2009) identified EFV in $12,5 \%$ of low risk pregnant women in a primary health care center, having compromised regulatory mechanisms as causal factor evidenced by edema in lower limbs. The term compromised regulatory mechanisms refers to the imbalance in the 
maintenance of body fluids. During the review two etiological factors were identified, they were prevenient from the imbalance in a pregnant women physiological state: vascular alterations related to pregnancy diseases and hormonal changes. These factors fit in NANDA-I classification of Associated Condition and Population at risk respectively. Associated conditions are medical diagnoses, lesions, procedures, medical devices or pharmaceutical agents; they are not independently modified by the nurse, although they can be of help to nurse diagnoses precision. Population at risk are a group of people that share some characteristic that makes each member susceptible to a specific human response ${ }^{(1)}$.

Excessive sodium intake appears as a risk factor for obesity, hypertension and anemia, as it is with other dangerous conditions during pregnancy ${ }^{(25)}$. Sodium and body water balance suffer alterations during gestational time so that pregnant women organism can control the increasing blood volume in circulation. An imbalanced diet, with high sodium level in food, predisposes pregnant women to fluid retention and its complications if no interventions are done to improve the diet, such as edema and alteration in blood pressure ${ }^{(21)}$. Excessive sodium intake acts as precipitating factor to EFV. Precipitating factors are those that initiate the causal chain ${ }^{(11)}$. Maintaining a high sodium level diet, in long term, increases the concentration of this ion, causing the cells to release fluid to circulation, this way increasing the circulating volume, leading to edema ${ }^{(5)}$.

Hormonal changes are directly related to the increased plasmatic volume in pregnancy. The estrogen, with elevated levels due to pregnancy $\left(10^{n} \mathrm{~g} / \mathrm{ml}\right)$, acts as stimulator of renin-angiotensinaldosterone system, leading to alterations in blood volume ${ }^{(4)}$. Other researchers point out the increase of corticotropin and estrogen and the engorgement of the blood vessels as components of the edematous effect ${ }^{(24)}$. During the review, this etiological factor was related to the clinical indicators edema, alteration in blood pressure, weight gain over short period of time, decreased hematocrit, decreased hemoglobin, dyspnea, orthopnea, paroxysmal nocturnal dyspnea and pulmonary congestion. During pregnancy, hormonal changes act as reinforcing factor to increasing plasmatic sodium concentration. Lopes, Silva and Herdman (2015) emphasize that reinforcing factors amplify the effects on a preexistent condition. Thus, hormonal changes turn higher the sodium retention on pregnant women organism, because they increase renin-angiotensin-aldosterone activity, leading to higher retention of sodium and water and, consequently, higher fluid retention ${ }^{(4,19)}$.

Still in hormonal changes and excessive sodium intake, with advance of pregnancy, mechanical factor appears as precipitating for fluid retention. Mechanical factor was noticed as causal specific factor of lower limbs edema, occurring with pregnancy evolution and increasing uterine volume. Pelvic and femoral vase compression increases hydrostatic pressure, causing vein dilatation, damaging the venous flow return, leading to lower limbs edema ${ }^{(24)}$. This factor can be marked as an Associated Condition due to the impossibility of being independently modified by the nurse, although its effects on edema can be diminished by nurse's orientation, like elevating or massaging lower limbs. The gravitational effect of uterine volume performs compression in iliac veins, difficulting venous flow return, leading to development or exacerbation of lower limbs edema and, also, to dyspnea due to difficulty in doing respiratory movements because of the increased uterine volume ${ }^{(24)}$.

Hormonal changes lead, still, to the appearance of other clinical indicators. Among them there are decreased hemoglobin and decreased hematocrit; such phenomenon occurs due to the increased plasmatic volume that is higher, proportionally, than the increase in erythrocyte production, causing pregnancy physiological anemia ${ }^{(26-28)}$. The increase in circulating blood volume and total peripheral resistance on third trimester of uncomplicated pregnancy cause a minor increase in CVP, but according to Abbas et al. (2005) it is not significant.

Fluid retention can also affect upper air ways, narrowing them, generating alterations in pregnant women respiratory pattern. Besides that, the increased circulating blood volume causes the increase in pulmonary flow leading, during the first gestational trimester, to pregnancy physiological dyspnea(30). Along with increased cardiac output due to pregnancy, the increased blood volume takes to an overload of the circulatory system, leading to increased pulmonary artery pressure ${ }^{(32-33)}$.

Hypertensive diseases lead to EFV due to increased capillary permeability caused by endothelial damage that occurs in this situation, leading to fluid extravasation ${ }^{(4)}$. This information is corroborated by the study of Kojima et al. (2013), a clinical case of preeclampsia, in which hydric retention in preeclampsia is consequence of endothelial leakage of plasma to the interstitial space. In hypertensive pregnant women, fluid retention is one of the signs to the possibility of PSHD occurrence. The loss of plasma to extravascular space is one of the compensatory mechanisms of arterial hypertension that results in the appearance of edema ${ }^{(43)}$. Along the search for clinical indicators of EFV, vascular alterations related to pregnancy diseases were associated to the following indicators: alteration in blood pressure, edema, orthopnea, paroxysmal nocturnal dyspnea (PND), pulmonary congestion, oligury, weight gain over short period of time and anasarca.

Vascular alterations related to pregnancy specific pathologies act as reinforcing factor of hormonal changes when they potentiate the effects of the pregnant women hypervolemic state. Rezende Filho \& Montenegro (2007) tell us that there is increase of blood pressure due to changes in vascular tone caused by DHEG. Due to the increased permeability caused by endothelial damage by DHEG, it occurs a bigger fluid leakage leading to generalized edema. Weight gain over short period of time reflects the generalized edema in this condition ${ }^{(34)}$.

This fluid overflow leads to decreased oncotic and pulmonary capillary hydrostatic pressure, turning the pregnant woman more susceptible to pulmonary congestion development, hence, respiratory complications such as orthopnea, paroxysmal nocturnal dyspnea and pulmonary congestion. Orthopnea and paroxysmal nocturnal dyspnea result from excessive venous return of fluid from lower limbs that reaches the lungs, overcharging them ${ }^{(35-36)}$. Thus, adopting horizontal positioning during the day or laying down to sleep causes respiratory distress, giving the woman a need to adopt a different position as sitting down or orthostatic.

The increased plasmatic volume, cardiac output, heart rate and capillary permeability and the decreased colloidosmotic pressure inherited to pregnancy are exaggerated in pregnant women 
with vascular alterations decurrent of DHEG and predispose to pulmonary congestion, since they have low intravascular colloidosmotic pressure due to the increased capillary endothelial permeability and proteinury ${ }^{(16,37,46)}$. This situation creates higher fluid retention and decreased hydrostatic pressure in alveolar spaces and pulmonary interstice, stopping the fluid to return circulation, turning the lungs to congest ${ }^{(30)}$.

Oligury appears as direct consequence of vascular alterations inherited of DHEG. Rezende Filho \& Montenegro (2007) show us that the most characteristic renal injury of DHEG is capillary glomerular endotheliosis, causing fluid leakage and decreasing renal glomerular filtration, leading to decreased urinary output and water and salt retention in the interstice.

DHEG is considered of idiopathic origin. Although, there are factors that may increase possibilities of a pregnant woman to develop that disease. Lopes, Silva \& Herdman (2015) consider such factors as incapacitating, thus they difficult recuperation or health maintenance. Presence of chronic diseases as hypertension, diabetes or obesity is a factor that increases risk of DHEG development. These conditions are considered of risk for being associated with subjacent vascular insufficiency and increased oxidative stress ${ }^{(19)}$. At the same time, extremes of reproductive age (below 18 years old and above 35 years old) and being on the first gestation were considered predisposing factors to vascular alterations, because they create a state of susceptibility to such condition, also being linked to oxidative stress ${ }^{(11,19)}$.

\section{Study limitations}

A possible limitation to this research may be the limited number of studies related to nursing diagnoses.

\section{Contributions to the nursing area}

Excessive fluid volume in higher or lower level is a cause of discomfort to the pregnant woman and must be considered during pre-natal care with nurses, adopting the available measures to improve the situation. The middle range theory created in this study may help in better understanding the interactions between causal factors of EFV and its clinical indicators, providing better visualization of its components relationships to nurse professionals as well as identifying possible intervention points for resolution or improvement of pregnant women health conditions.

\section{CONCLUSIONS}

Excess fluid volume is a nursing diagnosis that may be present both in healthy and complicated pregnancies. The present study identified, through integrative review, the following causal factors for EFV: chronic diseases (hypertension, obesity, diabetes), extremes of reproductive age (below 18 and above 35 years old), primiparity, excessive sodium intake, hormonal changes, mechanic factor and vascular alterations related to gestational pathologies. The clinical indicators related to the previous factors were: edema, decreased hematocrit, decreased hemoglobin, dyspnea, pulmonary congestion, weight gain in short period of time, alteration in blood pressure, alteration in pulmonary artery pressure, increased central venous pressure, oligury, orthopnea, paroxysmal nocturnal dyspnea, anasarca and changes in respiratory pattern.

Through middle range theory it was possible to identify causal relationships between etiological factors and how they lead to clinical indicators in EFV. Excessive sodium intake and mechanic factor were pointed out as precipitating for the causal chain that, associated with other factors as hormonal changes and vascular alterations, cause the occurrence of the clinical indicator previously discussed. While incapacitating factors, as chronic diseases, and predisposing factor as extremes of reproductive age and primiparity, make the pregnant woman more likely to the development of vascular alterations that might result in EFV.

Complications decurrent from fluid retention result both from health habits before and during pregnancy, as from alterations that occur due to pregnancy itself, which might be cardiovascular, pulmonary and renal, depending on how etiological factors will interact among each other. The odds of developing vascular alterations, that lead to EFV clinical indicators such as alteration in blood pressure and pulmonary congestion, may be decreased through primary care activities. Nursing professionals have the essential role in this matter when providing orientation to the maintenance of health habits and making interventions according to the pregnant woman needs.

\section{REFERENCES}

1. Herdman TH, Kamitsuru S. Diagnósticos de Enfermagem da NANDA: Definições e classificações, 2018-2020. Oxford: Wiley Blackwell, 2018.

2. Hall JE, Guyton AC. Tratado de Fisiologia Médica. 12. ed. Rio de Janeiro: Elsevier, 2011.

3. Rocha PN, Menezes JAV, Suassuna JHR. Avaliação hemodinâmica em paciente criticamente enfermo. J Bras Nefrol. 2010;32(2):201-12. doi: 10.1590/S0101-28002010000200009

4. Freitas F, Martins-Costa SH, Ramos JGL, Magalhães JA. Rotinas em Obstetrícia. 6. ed. Porto Alegre: Artmed, 2011, 904 p.

5. Potter PA, Perry AG. Fundamentos de Enfermagem. 8. ed. Rio de Janeiro: Elsevier, 2013.

6. Guimarães HCQCP, Barros ALBL, Gutierrez MGR. Identificação das características definidoras do diagnóstico de enfermagem excesso de volume de líquidos. Rev Latino-Am Enfermagem. 2000;8(2):68-73. doi: 10.1590/S0104-11692000000200011

7. Fawcett J. Contemporary nursing knowledge analysis and evaluation of nursing models and theories. 2nd ed. Philadelphia, PA: Davis Company, 2005.

8. Parker ME. Nursing theories and nursing practice. 2nd ed. Philadelphia, PA: Saunders, 2006. 
9. Villalobos MMD. Teoría de enfermería: ¿un camino de herradura? Aquichan[Internet]. 2007 [cited 2019 Jan 20];7(2):161-73. Available from: http://www.scielo.org.co/pdf/aqui/v7n2/v7n2a05.pdf

10. Peterson SJ, Bredow TS. Middle range theories: application to nursing research. 3rd edition. Philadelphia, PA: Wolters Kluwer Health/ Lippincott Williams \& Wilkins; 2013.

11. Lopes MVO, Silva VM, Herdman TH. Causation and Validation of Nursing Diagnoses: A Middle Range Theory. Int J Nurs Knowledge;2017;28(1):53-9. doi: 10.1111/2047-3095.12104

12. Moher D, Liberati A, Tetzlaff J, Altman DG. Preferred Reporting Items for Systematic Reviews and Meta-Analyses: The PRISMA Statement. The PRISMA Group. PLOS Med. 2009;6(7):e1000097. doi: 10.1371/journal.pmed.1000097

13. Coelho EB. Mecanismos de formação de edema. Proceedings of SIMPÓSIO: SEMIOLOGIA. Ribeirão Preto: Med. 2004;(37):189-198.

14. Boery RNSO, Barros ALBL, Lucena, AF. Características definidoras do diagnóstico de enfermagem: volume de líquidos excessivo. Rev Gaúcha Enferm [Internet]. 2005[cited 2019 Jan 20];26(3):326-32. Available from: https://seer.ufrgs.br/RevistaGauchadeEnfermagem/article/ view/4563/2490

15. Aguiar MIF, Freire PBG, Cruz IMP. Sistematização da assistência de enfermagem a paciente com síndrome hipertensiva específica da gestação. Rev Rene [Internet]. 2010 [cited 2019 Jan 20];11(4):66-75. Available from: http://www.periodicos.ufc.br/rene/article/ view/4600/3445

16. Razeq SSA. Obstetric emergencies: respiratory distress. Contemporary Ob Gyn. 2011;56(11):28-35.

17. Ministério da Saúde (BR). Secretaria de Atenção à Saúde. Departamento de Atenção Básica. Atenção ao pré-natal de baixo risco. Brasília (DF); 2012.

18. Jarvis C. Exame físico e avaliação de saúde para enfermagem. 6a Ed. Rio de Janeiro: Guanabara Koogan, 2012.

19. Rezende Filho J, Montenegro CAB. Obstetrícia fundamental. 11 a edição. Rio de Janeiro: Editora Guanabara Koogan, 2007.

20. Rothman KJ, Greenland S, Lash TL. Modern epidemiology. 3rd ed. Philadelphia: Lippincott Williams \& Wilkins, 2013.

21. Moura, ERF, Oliveira CGS, Damasceno AKDC, Pereira MMQ. Fatores de risco para síndrome hipertensiva específica da gestação entre mulheres hospitalizadas com pré-eclâmpsia. Cogitare Enfermagem. 2010;15(2):250-55. doi: 10.5380/ce.v15i2.17855

22. Leite MCA, Nóbrega MM, Nóbrega MML. Diagnósticos de enfermagem em gestantes atendidas em unidade de saúde da família. Rev Enferm UFPE. 2009;3(2):292-300. doi: 10.5205/reuol.202-1995-3-CE.0302200913

23. Kojima T, Yamada T, Yamada T, Morikawa M, Cho K, Minakami H. Unusual clinical course of preeclampsia heralded by generalized edema. J Obstet Gynaecol Res, 2013, 39(11): 1538-1540. doi: 10.1111/jog.12080

24. Ponnapula P, Boberg JS. Lower extremity changes experienced during pregnancy. J Foot Ankle Surg, 2010;49(5):452-458. doi: 10.1053/j. jfas.2010.06.018.

25. Santana JM, Queiroz VAO, Brito SM, Santos DB, Assis AMO. Food consumption patterns during pregnancy: a longitudinal study in a region of the North East of Brazil. Nutr Hosp. 2015;1(32):130-8. doi: 10.3305/nh.2015.32.1.8970

26. Costa CM, Brum IR, Lima ES. Anemia e marcadores séricos da deficiência de ferro em grávidas atendidas na rede pública municipal de Manaus, Amazonas, Brasil. Acta Amaz. 2009;39(4): 901-6. doi: 10.1590/S0044-59672009000400018

27. Gernand AD, Christian P, Schulze KJ, Shaikh S, Labrique AB, Shamim AA, West Jr KP. Maternal nutritional status in early pregnancy is associated with body water and plasma volume changes in a pregnancy cohort in Rural Bangladesh. J Nutr. 2012;142(6):1109-15. doi: 10.3945/jn.111.155978

28. Kaaja RJ, Greer IA. Manifestations of chronic disease during pregnancy. Jama. 2005;294(21): 2751-7. doi: 10.1001/jama.294.21.2751

29. Abbas AE, Lester SJ, Connolly H. Pregnancy and the cardiovascular system. Int J Cardiol. 2005;98(2):179-89. doi: 10.1016/j.ijcard.2003.10.028

30. Bauer ST, Cleary KL. Cardiopulmonary complications of pre-eclampsia. Semin Perinatol. 2009;33(3):158-65. doi: 10.1053/j. semperi.2009.02.008

31. Bobrowski RA. Pulmonary physiology in pregnancy. Clin Obstet Gynecol. 2010;53(2):285-300. doi: 10.1097/GRF.0b013e3181e04776

32. Higton AM, Whale C, Musk M, Gabbay E. Pulmonary hypertension in pregnancy: two cases and review of the literature. Intern Med J. 2009;39(11):766-70. doi: 10.1111/j.1445-5994.2009.02051.x

33. Gei A, Rueda CM. Pulmonary Hypertension and Pregnancy: An Overview. Clin Obstet Gynecol. 2014;57(4):806-26.2014. doi: 10.1097/ GRF.0000000000000076

34. Mamun AA, Callaway LK, O'Callaghan MJ, Williams GM, Najman JM, Alati R, et al. Associations of maternal pre-pregnancy obesity and excess pregnancy weight gains with adverse pregnancy outcomes and length of hospital stay. BMC Pregnancy Childbirth. 2011;11(1):11-20. doi: 10.1186/1471-2393-11-62

35. Belen E, Tipi FF, Helvaci A, Bayyigit A. Concurrent early-onset peripartum cardiomyopathy in a preeclampsia patient with acute pulmonary edema. Intern Med. 2015;54(8):925-7. doi: 10.2169/internalmedicine.54.2714

36. Ko ML, Chen SC, Huang LW, Chang JZ, Huang LW, Hwang JL, et al. Massive ascites complicating pre-eclampsia. Taiwanese J Obstet Gynecol. 2005;44(3):267-9. doi: 10.1016/S1028-4559(09)60151-0

37. Poole JH, Spreen DT. Acute pulmonary edema in pregnancy. J Perinat Neonat Nurs. 2005;19(4):316-31. 
38. Gil MLA, Ramos LMA, Castrillón JJC, Giraldo JF, Vélez AFH, Bucheli AML, et al. Prevalencia de los trastornos hipertensivos del embarazo en mujeres embarazadas controladas en Assbasalud E.S.E, Manizales (Colombia), 2006 a 2008. Arch Med. 2010;10(2):139-50.

39. Albino MAS, Moccellin AS, Firmento BS, Driusso P. Modificações da força de propulsão da marcha durante a gravidez: das alterações nas dimensões dos pés. Rev Bras Ginecol Obstet. 2011;33(7):164-9. doi: 10.1590/S0100-72032011000700008

40. Henry F, Quatresooz P, Lopez JCV, Piérard GE. Blood vessel changes during pregnancy. Am J Clin Dermatol. 2006;7(1):65-9. doi: 10.2165/00128071-200607010-00006

41. Katz L, Amorim MMRD, Miranda GV, Silva JLP. Perfil clínico, laboratorial e complicações de pacientes com síndrome HELLP admitidas em uma unidade de terapia intensiva obstétrica. Rev Bras Ginecol Obstet. 2008;30(2):80-6. doi: 10.1590/S0100-72032008000200006

42. Mochhoury L, Razine R, Kasouati J, Kabiri M, Barkat A. Body mass index, gestational weight gain, and obstetric complications in Moroccan population. J Pregnancy. 2013;(2013):1-6. doi: 10.1155/2013/379461

43. Reiners AAO, Dióz M, Teixeira NZF, Gonçalves PMS. Diagnósticos de enfermagem em gestantes hipertensas. Rev Min Enferm. 2009;2(13):232-7. doi: S1415-27622009000200010

44. Facco FL. Sleep-Disordered Breathing and Pregnancy. Semin Perinatol. 2011;35(6):335-9. doi: 10.1053/j.semperi.2011.05.018

45. Alexander JM, Wilson KL. Hypertensive emergencies of pregnancy. Obstet Gynecol Clin North Am [Internet]. 2013 [cited 2019 Jan 20];40(1):89-101. Available from: https://pubmed.ncbi.nlm.nih.gov/6764393/

46. Mighty HE. Acute respiratory failure in pregnancy. Clin Obstet Gynecol. 2010;53(2):360-8. doi: 10.1097/GRF.0b013e3181deb3f1

47. Gyselaers W, Mesens T, Tomsin K, Peeters L. Doppler assessment of maternal central venous hemodynamics during uncomplicated pregnancy: a comprehensive review. Facts Views Vis Obgyn [Internet]. 2009;1(3):171-81. Available from: https://www.ncbi.nlm.nih.gov/pmc/ articles/PMC4255508/

48. Turner JA. Diagnosis and management of pre-eclampsia: an update. Int J Womens Health. 2010;2:327-37. doi: 10.2147/IJWH.S8550

49. Assunção PL, Melo ASO, Gondim SSR, Benício MHA, Amorim MMR, Cardoso MAA. Ganho ponderal e desfechos gestacionais em mulheres atendidas pelo Programa de Saúde da Família em Campina Grande, PB (Brasil). Rev Bras Epidemiol. 2007;10(3):352-60. doi: 10.1590/ S1415-790X2007000300006

50. Chummun H. Hypertension-a contemporary approach to nursing care. Brit J Nursing. 2009;18(13). doi: 10.12968/bjon.2009.18.13.43204 